\title{
EFEITO DA LASERTERAPIA NA CICATRIZAÇÃO DE ÚLCERA SACRAL DE DECÚBITO
}

\author{
BASTOS, L.L.S., FERREIRA, K.L., SOUSA, L.M. SOARES, M.A., SANTANA, C.G. \\ Clínica Escola Maria Auxiliadora - CEMA, Institutos Superiores de Ensino do CENSA - \\ ISECENSA, Rua Salvador Correa, 272, Centro, Campos dos Goytacazes, RJ, Brasil.
}

A úlcera de decúbito pode ser definida como uma lesão localizada que ocorre quando a pressão intersticial excede a pressão intracapilar, originando uma deficiência de perfusão capilar. Esse fato impede o transporte de nutrientes ao tecido, usualmente sobre uma proeminência óssea, resultante de pressão, ou pressão associada a cisalhamento e/ou fricção. O tratamento de laserterapia tem o intuito de promover como principais efeitos fisiológicos resolução anti-inflamatória, neoangiogênese, proliferação epitelial e de fibroblastos, síntese e deposição de colágeno, revascularização e contração da ferida, resultando em sua cicatrização. Avaliar a ação da laserterapia e ledterapia na cicatrização da úlcera sacral de decúbito através da biotofogrametria. $\mathrm{O}$ tratamento foi aplicado no paciente do gênero masculino, 19 anos de idade, estudante. No seu histórico de lesão, sofreu um acidente motociclístico no dia 04 de Dezembro de 2014. Fez fratura das vértebras cervicais c6-c7 com compressão medular e um traumatismo raquimedular (TRM) em nível da décima vértebra torácica (T10). Permaneceu por 12 dias no hospital local à espera de transferência para um hospital de outra cidade para a realização de uma artrodese. A cirurgia foi realizada no dia 15 de Dezembro de 2014. No dia 08 de janeiro de 2015, o paciente deu entrada no setor de fisioterapia da Clínica Escola Maria Auxiliadora (CEMA). No exame físico-funcional foi detectada uma plegia de membros inferiores e uma paresia de membros superiores. Na inspeção foi observado uma úlcera sacral contaminada com área de $37 \mathrm{~cm} 2$, através da biofotogrametria realizada com Iphone $5 \mathrm{~S}$ a uma distância de $20 \mathrm{~cm}$, sendo feita a medida linear da área no ImageJ. Fisiodiagnóstico fechado em perda da motricidade, ausência de controle de tronco e hiporreflexia de membros superiores. No primeiro mês de tratamento, foi utilizado Laser vermelho (10 J 8 Pontos) e LED azul 4 pontos de 1 minuto. No segundo mês utilizou o Laser vermelho (8 J - 8 Pontos) e LED azul 4 pontos de 1 minuto. No terceiro mês utilizou o Laser vermelho (6 J - 8 Pontos) e LED azul 4 pontos de 1 minuto. E no quarto e último mês de tratamento foi realizado Laser vermelho (6J - 4 Pontos) e LED azul 4 pontos de 1 minuto. Além do tratamento da úlcera, foi realizado um trabalho para reeducação funcional. A área mensurada no momento pré aplicação era de $37,6 \mathrm{~cm}^{2}$. Após o primeiro mês de tratamento, a área calculada foi de $28 \mathrm{~cm}^{2}$. No mês seguinte a área da ferida reduziu para $23,7 \mathrm{~cm}^{2}$. No terceiro mês de tratamento a área reduziu para $11 \mathrm{~cm}^{2}$. E no quarto e último mês a ferida foi mensurada em $5,1 \mathrm{~cm}^{2}$ de área. $\mathrm{O}$ Laser de baixa potência foi eficaz até o momento no processo de cicatrização da úlcera sacral, sendo altamente indicado para tratamento de feridas cutâneas.

Palavras chaves: laser de baixa potência, úlcera de pressão e biofotogrametria 


\section{REFERÊNCIAS}

ANDRADE, F.S.S.D, Clark R.M.O, Ferreira M.L. Efeitos da laserterapia de baixa potência na cicatrização de feridas cutâneas. Rev Col Bras Cir.[periódico na Internet] 2014;41(2). Disponível em URL: http://www.scielo.br/rcbc

WADA, A., Teixeira, N. N, Ferreira, M. C. Úlceras por pressão. Rev Med (São Paulo). 2010 jul.- dez. 